Türk Turizm Araştırmaları Dergisi
ASS20,4(3): $2840-2855$.

\title{
Yöneticilerin İşkolik Davranışlarının Yaşam Doyumlarına Etkisi: Konaklama İşletmeleri Örneği
}

Ebru GERDAN, Yüksek Lisans Öğrencisi Balıkesir Üniversitesi, Sosyal Bilimler Enstitüsü, Balıkesir, e-posta: ebru.gerdan@baun.edu.tr ORCID: https://orcid.org/0000-0001-6713-4271

Doç. Dr. Bayram ŞAHIN, Balıkesir Üniversitesi, Turizm Fakültesi, Balıkesir, eposta: bsahin@balikesir.edu.tr ORCID: https://orcid.org/0000-0002-1911-9066

Öz

Günümüz dünyasında artan rekabet ve teknolojik gelişmeler çalışma koşullarında da birtakım değişimlere neden olmuş, çalışmaya ilişkin mekân ve zaman önemini yitirmiş, çalışanlar artık iş yerlerinden bağımsız olarak, işlerini istedikleri yerden ve istedikleri zaman yürütebilir hale gelmişlerdir. Bu değişim, çalışanları çalışma saatlerinin dışında da çalışmaya itmiş ve çalışanların işe ayırdığı zamanın sınırlarının ortadan kalkmasına ve birer işkoliğe dönüşmelerine neden olmuştur. İşkoliklik, bireyler üzerinde tükenmişlik, işten kaçma eğilimi, örgütsel amaçlardan uzaklaşma verimliliğin düşmesi, iş yaşamı ve özel yaşamı arasında denge kuramama ve yaşam doyumunda düşüş yaşamasına sebep olmaktadır. Özellikle turizm sektörü gibi çalışma saatlerinin fazla olduğu sektörlerde daha fazla görülmektedir. Bu amaçla araştırmada İstanbul ilindeki konaklama işletmelerinde çalışan 400 yöneticinin işkolik davranışlarının yaşam doyumlarına etkisi incelenmiştir. Araştırma sonucunda işkoliklik ve yaşam doyumu açısından cinsiyet değişkeninin anlamlı bir fark yarattığı tespit edilmiş ve kadın yöneticilerin işkolik eğilimleri ve yaşam doyumlarının daha yüksek olduğu sonucuna ulaşılmıştır. Ayrıca işkoliklik ile yaşam doyumu arasında anlamlı ve pozitif yönlü ilişki bulunmuştur.

Anahtar Kelimeler: İşkoliklik, Yaşam Doyumu, Yöneticiler, Konaklama İşletmeleri.

Makale Gönderme Tarihi: 06.05.2020

Makale Kabul Tarihi: 04.07.2020

\section{Önerilen Atıf:}

Gerdan, E. ve Şahin, B. (2020). Yöneticilerin İşkolik Davranışlarının Yaşam Doyumlarına Etkisi: Konaklama İşletmeleri Örneği, Türk Turizm Araştırmaları Dergisi, 4(3): 2840-2855.

(C) 2020 Türk Turizm Araştırmaları Dergisi. 


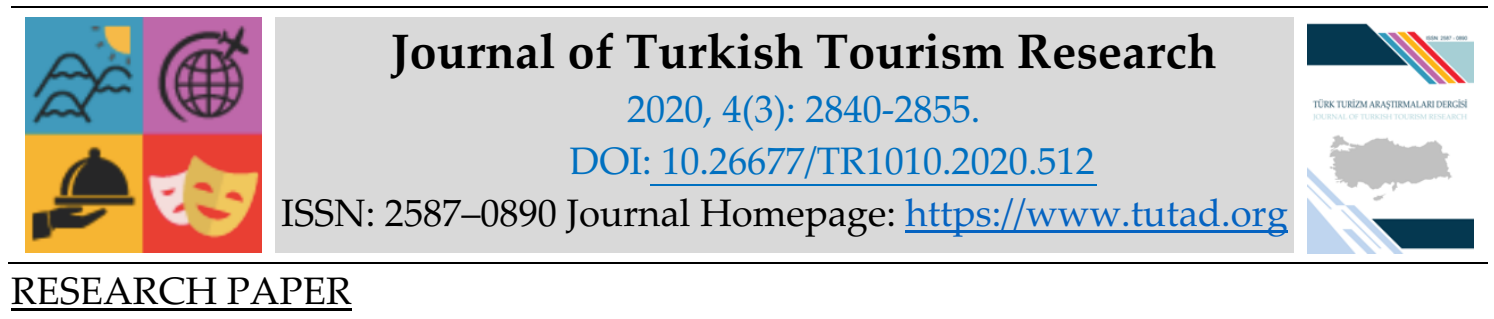

\title{
The Effect of Managers' Workaholic Behaviors on Life Satisfaction: Example of Accommodation Enterprises
}

Ebru GERDAN, MSc. Student, Balıkesir University, Social Sciences Institute, Balıkesir, email: ebru.gerdan@baun.edu.tr ORCID: https://orcid.org/0000-0001-6713-4271

Associate Prof. Dr. Bayram ŞAHIN, Balıkesir University, Faculty of Tourism, Balıkesir, email: bsahin@balikesir.edu.tr ORCID: https://orcid.org/0000-0002-1911-9066

\begin{abstract}
In today's world, increasing competition and technological developments have caused some changes in working conditions, employees are now able to carry out their jobs, irrespective of their place of work wherever and whenever they want. This change has pushed employees to work outside working hours and has caused employees to limit their time to work and turn them into a workaholic. Workaholicism, burn out on individuals, the tendency to escape from work, the decrease of efficiency from organizational goals, the balance between work life and private life and cause a decrease in life satisfaction. It is more common in sectors such as tourism sector where working hours are high. For this purpose, the effect of the workaholic behaviors of 400 managers working in the accommodation establishments in the province of İstanbul on life satisfaction was investigated. As a result of the research, it was determined that the gender variable made a significant difference in terms of workaholicity and life satisfaction and it was determined that the workaholic tendencies and life satisfaction of female managers were higher. In addition, a significant and positive relationship was found between workaholics and life satisfaction.
\end{abstract}

Keywords: Workaholic, Life Satisfaction, Managers, Accommodation Enterprises.

Received: 06.05.2020

Accepted: 04.07.2020

\section{Suggested Citation:}

Gerdan, E. and Şahin, B. (2020). The Effect of Managers' Workaholic Behaviors on Life Satisfaction: Example of Accommodation Enterprises, Journal of Turkish Tourism Research, 4(3): 2840-2855.

(C) 2020 Türk Turizm Araştırmaları Dergisi. 


\section{Gíriş}

Günümüz rekabet ortamında çalışma koşullarının hızla değişmesi, bireylerin kariyerinde yükselme arzuları, çalışanların ekonomik krizler sonucu işten çıkarılma ve işsiz kalma korkusu, gelişen teknolojiyle birlikte çalışma ortamlarının ofis dışına taşınması, evliliklerde yaşanan bir takım sorunlar, çalışanların yaşamlarını ihmal etmelerine ve daha fazla işlerine zaman ayırmalarına neden olmaktadır. Bu durum çalışanların yaşamında işin merkezi bir konum kazanmasına ve işkoliklik davranışının oluşmasına neden olmuştur. İşkoliklik, bireylerin sahip oldukları zamanın büyük bir kısmını iş yerinde geçirmesi, çalışma saatleri dışında da işiyle ilgili konu ve alanlarla uğraşması ve işine karşı aşırı bir bağımlılık duyması olarak ifade edilmektedir. İşkoliklik davranışının tartışıldığı ilk yıllarda bireyin çalışma performansını artıran olumlu bir durum olarak değerlendirilmiş olsa da zamanla bireyin sağlığına ve toplumsal ilişkilerine zarar vermesi işkolikliğin olumsuz olarak değerlendirilmesine sebep olmuştur (Robinson, 1996; Porter, 2001; Kanai ve Wakabayashi, 2001; Snir ve Harpaz, 2004; Mcmillan vd., 2004; Kart, 2005; Temel, 2006; Schaufeli vd., 2008). Ancak çalışma koşulları bireyleri bulunduğu organizasyonda varlığını sürdürebilmek, pozisyonunu kaybetmemek, organizasyondaki en başarılı kişi olabilmek gibi sebeplerle işlerinde daha fazla zaman geçirmeye ve çalışmaya zorlamaktadır. Bu durum bireylerin birer işkoliğe dönüşmesine sebep olmaktadır. Özellikle emek-yoğun özellik gösteren, krizlerden derin ve uzun süreli etkilenen, düzensiz ve yoğun çalışma saatlerine maruz kalan turizm sektöründe çalışan bireylerin işkolik davranışlar göstermeleri kaçınılmazdır. İşkolikliğin kaçınılmaz olduğu günümüzde, en riskli grupların başında yer alan yöneticilerinin işkolik davranışları ve yaşam doyumu düzeylerinin incelenmesi ve aralarındaki ilişkinin ortaya konulmasının önemli olduğu düşünülmektedir.

$\mathrm{Bu}$ araştırmayı önemli kılan nedenlerin başında alan yazını incelendiğinde işkoliklik ile yapılan araştırmaların genellikle öğretmenler (Akın ve Oğuz, 2010; Özdemir, 2013), sağlık çalışanları (Zincirkıran, 2014; Özsoy vd., 2015), hukuk çalışanları (Russo ve Waters, 2006; Gürel ve Altunoğlu, 2016) ve banka çalışanları (Dosaliyeva, 2009; Salihoğlu, 2014) üzerine yapıldığı görülmektedir. Ancak yöneticiler üzerine yapılan çalışmalar oldukça sınırlıdır. Oysaki işkolik davranış gösterme konusunda en riskli grupların başında yöneticiler yer almaktadır. Ayrıca işkoliklik kavramı tükenmişlik (Salmela-Aro ve Nurmi, 2004; Schaufeli vd., 2009), iş doyumu (Burke, 2001; Altınkurt ve Yllmaz, 2015) aile (Bonebright vd., 2000; Brady vd., 2008), örgütsel bağlllık (Tiftik ve Zincirkıran, 2014) kavramlarıyla ilişkilendirildiği görülmektedir. Yerli ve yabancı literatür incelendiğinde, işkoliklik ve yaşam doyumu değişkenlerinin birlikte ele alındığı çalışmalar ise sınırlı sayıdadır (Bonebright vd., 2000; Harpaz ve Snir, 2003; Burke vd., 2004; Shimazu ve Schaufeli, 2009; Gürel ve Altunoğlu, 2016). Turizm sektöründe ise işkoliklik ile yaşam doyumu kavramlarının birlikte ele alındığı herhangi bir çalışmaya rastlanmamıştır. Bu sebeple araştırmanın hem turizm yazınına hem de sektöre katkı sağlayacağı öngörülmektedir.

\section{KAVRAMSAL ÇERÇEVE}

\section{İșkoliklik}

İşkoliklik kavramı ilk kez 1968 yılında Amerikalı bir psikolog ve din eğitmeni olan Wayne Oates tarafından alkoliklik teriminden esinlenerek bireylerin işe ve çalışmaya karşı aşırı düşkünlüğünü ifade etmek amacıyla türetilmiş ve 1971 yılında Oates'ın yayınladığı "Bir İşkoliğin İtiraflarıConfessions of a Workaholic" isimli kitabında ilk kez yer almıştır (Snir ve Harpaz 2004; Snir vd., 2006; Yaniv, 2011). Akademik alanda ise işkoliklik kavramı ilk kez Spence ve Robbins'in (1992) araştırmasında kullanılmıştır. Spence ve Robbins (1992) işkolikliği, bireylerin işlerine aşırı düşkünlüğünden ötürü diğer yaşamsal faaliyetlerden uzak kalması, bu faaliyetleri yaparken bile 
zihinsel olarak işinden kopamama durumu olarak tanımlamıştır. Robinson ve Post (1997), işkolikliği bireyin sürekli işine odaklanması, işini yaşamının merkezi olarak görmesi bunun sonucunda işinin, kişisel değerlerinin ve ilişkilerinin önüne geçmesi durumu olarak tanımlamaktadırlar. Müller ve Schotter (2010)'e göre işkoliklik, bireyin kendini çalışmaktan alıkoyamamasıdır.

Birçok bilim insanı ise işkoliklik kavramını çalışma saatlerini esas alarak tanımlamıştır. Literatür incelendiğinde bazı araştırmacılar haftada 50 saat ve daha uzun sürelerde çalışanları işkolik olarak kabul ederken (Spence ve Robbins, 1992; Broeck vd., 2011), bazı araştırmacılar ise haftada 60 saat ve daha uzun sürede çalışanları işkolik olarak kabul etmiş (Fujimoto, 2014), bazı araştırmacılarda günlük çalışma saatlerini esas alarak 11,5 saat ve daha uzun sürelerde çalışanları işkolik olduğunu savunmuştur (Snir ve Zohar, 2008). İşkoliklik kavramının yalnızca süre açısından ele alınmasının yanlış olduğunu savunan araştırmacılarda olmuştur. Mudrack ve Naughton (2001) yapmış oldukları çalışmada işgörenlerin iş koşulları nedeniyle normal haftalık çalışma saatleri üzerinde çalışabileceklerini, bu bireyleri işkolik olarak değerlendirilmesinin yanlış olduğunu savunmuştur. Buelens ve Poelmans (2004)'da çalışma koşulları nedeniyle uzun süre çalışan işgörenlerin "zorunlu çok çalışanlar" olarak isimlendirmiş ve bu bireylerin işkolik olarak değerlendirilmemesi gerektiğini savulmuştur.

Bazı araştırmacılar işkolikliğin olumlu sonuçlar doğurduğuna ilişkin düşünceleri savunurken (Burke, 2000) bazı araştırmacılarda işkolikliği olumsuz sonuçlar doğurabildiğini savunmuşlardır (Spence ve Robbins, 1992; Porter, 2001; Harpaz ve Snir, 2003; Shimazu ve Schaufeli, 2009). İşkolikliği olumlu bir davranış olarak değerlendiren araştırmacılar durumu örgütsel/kurumsal boyutta ele almış ve işkolikliği çalışmaya karşı aşırı istekli ve işini çok sevme durumu olarak değerlendirmişlerdir (Snir ve Harpaz, 2004). İşkolikliğin olumlu bir davranış olduğunu üretim açısından çalışma hayatında önemli kişiler olduğunu savunan araştırmacılar (Machlowitz, 1979; Burke, 2000; West, 2001; Peiperl ve Jones, 2001) işkoliklerin aynı zamanda iş tatmini ve verimlilik düzeylerinin de yüksek olduğu savunmuşlardır. Seybold ve Salomone (1994) işkolikliği, bireyin işini çok sevmesi ve işe karşı aşırı bir bağlılık duyması şeklinde tanımlamış ve işkolik bireylerin işte yaratıcı olduğunu bu yüzden de verimliliği ve iş doyumunu da olumlu yönde etkilediği ifade etmiştir.

İşkolikliğin olumsuz etkileri olduğunu savunan araştırmacılar da mevcuttur. Shimazu ve Schaufeli (2009), araştırmasında işkolikliğin bireylerin yaşam doyumuna, sağllğına ve iş performansına olumsuz yönde etkilediği sonucuna ulaşmışlardır. İşkolik çalışanlar, örgüte kısa vadede katkı sağlıyor olsalar da uzun vadede olumsuz sonuçlara neden olabilmektedir. İşkolik bireylerde zaman içerisinde tükenmişlik, işten kaçma eğilimi, örgütsel amaçlardan uzaklaşma, aile ve sosyal ilişkilerde sorunlara neden olduğu görülmektedir (Robinson, 1996a; Porter, 2001; Harpaz ve Snir, 2003; Mcmillan vd., 2004; Kart, 2005; Balducci vd., 2012). Ayrica bazı araştırmacılar işkolikliğin evliliklerde sorunlara, düşük aile tatmini ve iş ve aile yaşamlarında çatışmaların yaşanmasına neden olduğunu ifade etmişlerdir (Bonebright vd., 2000; Hill vd., 2001; Buelens ve Poelmans, 2004; Taris vd., 2005; Jonstone ve Jonston, 2005; Russo ve Waters, 2006; Vodanovich vd., 2007; Brady vd., 2008; Bakker vd., 2009; Shimazu vd., 2011: 400).

Yapılan araştırmalar incelendiğinde işkolikliğin olumsuz özelliklerin olumlu özelliklerinden daha fazla olduğu görülmektedir (Libano vd., 2010: 143). İşkoliklik davranışın incelenmeye başlanıldı̆̆ı dönemde bireyin çalışma performansını artıran olumlu bir durum olarak değerlendirilmiş olsa da zamanla bireyin sağllğına ve toplumsal ilişkilerine zarar vermesi işkolikliğin olumsuz olarak değerlendirilmesine sebep olmuştur (Robinson, 1996; Porter, 2001; Kanai ve Wakabayashi, 2001; Snir ve Harpaz, 2004; Mcmillan vd., 2004; Kart, 2005; Schaufeli, vd., 2008). Bireylerin işkoliklik düzeyi artıkça hem fiziksel olarak hem psikolojik olarak hem de örgütsel olarak bir takım olumsuzluklara maruz kalacak ve bunun sonucunda mutsuz, tükenmiş, 
aile ile sosyal ilişkileri zedelenmiş bireyler haline dönüşeceklerdir. Bu durumda bireylerin yaşam doyumlarında da düşüş yaşamasını olası hale getirecektir.

\section{Yaşam Doyumu}

Pozitif psikoloji düşüncesinin ortaya çıkmasıyla birlikte bilim insanları depresyon, mutsuzluk, kaygı, stres gibi kavramlar üzerinde araştırmalar yapmayı geride bırakmış ve "insan nasıl mutlu olur?" sorusuna cevap aramaya başlamışlardır. Bu arayış sonucunda öznel iyi oluş, mutluluk, yaşam kalitesi ve yaşam doyumu kavramları önem kazanmaya başlamış ve yaşamdan doyum almanın bireyin ruh sağlığı üzerinde önemli bir etken olduğu sonucuna ulaşmışlardır (Neugarten vd., 1961; Diener vd., 1985; Myers ve Deiner, 1995). Bu sonuç yaşam doyumu kavramının önemini ortaya koymaktadır. Yaşam doyumu kavramı ilk kez Neugarten ve arkadaşları (1961) tarafından ele alınmıştır. Neugarten ve arkadaşları (1961) yaşam doyumunu, kişinin beklentileriyle, sahip olduklarının karşılaştırılması sonucunda elde edilen durum ya da sonuç olarak tanımlamıştır. Myers ve Diener (1995), kişilerin temel olarak yaşam alanlarına ilişkin yapmış oldukları değerlendirme olarak tanımlamıştır. Yaşam doyumu bireyin yaşamdan beklentileri karşılandığı ölçüde gerçekleşir (Christopher, 1999: 143). Zhao vd., (2011)'ye göre yaşam doyumu, kişinin tüm yaşama ilişkin genel iyi olma durumunun ölçüm değerlendirmesi olarak tanımlamaktadır. Ayrıca alan yazında yaşam doyumunun bilişsel ve duyuşsal kuramlara göre de farklı tanımlandığı görülmektedir (Diener vd., 1985). Bilişsel kuram anlayışına göre yaşam doyumu, bireylerin istek, ihtiyaç ve beklentilerinin karşılanması ve yaşamında elde ettiği başarıların belirlemiş olduğu standartlarla karşılaştırmasına bağlı olarak oluşan bilişsel yargisı şeklinde tanımlanmaktadır (Lindfords vd., 2007: 816). Duyuşsal ya da duygusal kuramda yaşam doyumu ise, bireyin olumlu duyguları ile olumsuz duygularının dengelenmesi sonucu ortaya çıan ruh halidir (Diener vd., 1985a). Olumlu duyguların olumsuz duygulardan daha fazla deneyimlenmesi yaşam doyumunun yüksek olduğunu göstermektedir (Larsen vd., 1985: 7).

Yaşam doyumu kavramı, gerek akademik yazında gerekse günlük yaşantımızda oldukça sık kullanılan bir kavram olsa da ifade şeklinin kişiden kişiye farklılık göstermesi kavram üzerinde anlam karmaşası yaşanmasına sebep olmuştur (Büber, 2017). Alan yazın incelendiğinde yaşam doyumu yerine öznel iyi olma, mutluluk ve yaşam kalitesi kavramları kullanıldığı görülmektedir (Diener, 1994; Dost, 2007: 133). Ancak bu kavramlar arasında kuramsal açıdan bazı farklılıklar bulunmaktadır (Veenhoven, 2000). Öznel iyi oluş, bireyin yaşamına ilişkin duygusal ve bilişsel değerlendirmesidir (Diener vd., 1985a; Schimmack vd., 2002). Yaşam doyumu, öznel iyi oluşun bilişsel bileşeni olup kişinin kendi belirlediği kriterlere uygun olarak tüm yaşamını değerlendirmesi olarak tanımlanabilir (Yetim, 1991). Başka bir ifadeyle yaşam doyumu, öznel iyi oluşun bir alt boyutudur (Sahranç, 2007: 96). Literatürde yaşam doyumu ile karıştırılan aynı anlamda kullanılan bir diğer kavram da mutluluk kavramıdır (Proctor vd., 2009). Mutluluk kavramı, bütün isteklere, özlemlere sürekli ve eksiksiz bir şekilde erişme sonucu duyulan sevinç olarak tanımlanmakta ve gelecekte de hep iyi olma umudunu içermektedir (Karabacak, 2013: 25). Bir diğer karıştırılan kavram ise yaşam kalitesidir. Yaşam kalitesi, tatmin edildiğinde ya da karşılandığında kişilere mutluluk ve doyum verecek olan istek ve ihtiyaçlar bütünü olarak tanımlanabilir (Dündar, 1993: 50).

\section{YÖNTEM}

\section{Amaç}

Çalışmanın temel amacı, konaklama işletmeleri yöneticilerinin işkoliklik ve yaşam doyumu düzeyleri arasındaki ilişkiyi belirlemektir. Ayrıca, çeşitli demografik ve sosyo-ekonomik 
değişkenlerle birlikte çalışma koşullarının yöneticilerin işkoliklik ve yaşam doyumu üzerinde bir farka neden olup olmadığının belirlenmesi de çalışmanın bir diğer amacıdır.

\section{Evren ve Örneklem}

Araştırmanın örneklemi belirlenirken kolayda örneklem yöntemi uygulanmıştır. Verilerin toplanmasında ise nicel araştırma yöntemlerinden anket tekniği kullanılmıştır. Araştırmanın evrenini İstanbul ilinde faaliyet gösteren konaklama işletmelerindeki yöneticiler oluşturmaktadır. Anket 2018 Mayıs- Ağustos aylarında uygulanmıştır. Uygulama sürecinde 450 adet anket dağıtılmış, bu süreç sonunda 427 anket elde edilmiştir. Bu anketlerin 27 'si eksik veya hatalı işaretlemelerden dolayı değerlendirmeye alınmamış, böylece örneklemin son büyüklüğü 400 olarak belirlenmiştir. Araştırmada elde edilen veriler SPSS 21.0 paket programı ile analiz elde edilmiştir.

\section{Veri Toplama Araç ve Teknikleri}

Araştırma için kullanılacak veriler anket yöntemi ile toplanmıştır. Hazırlanan anket formu 3 bölümden oluşmaktadır. Birinci bölümde araştırmaya katılan yöneticilerin demografik özelliklerinin tespitine ilişkin sorular yer almaktadır. İkinci bölüm yöneticilerin işkoliklik düzeylerini belirlemek amacıyla Spence ve Robbins (1992) tarafından geliştirilen ve Kart (2005) tarafından Türk kültürüne uyarlanan İşkoliklik Envanteri kullanılmıştır. Ölçekte değerlendirme ölçeği olarak 5'li Likert Ölçeği kullanılmıştır. Anket formunun üçüncü bölümünde ise Diener, Emmons, Larsen ve Griffin (1985a) tarafından geliştirilen yaşam doyum ölçeği kullanılmıştır. Ölçek, Yetim (1991) tarafından Türkçeye uyarlanmıştır. Ölçeğin iç tutarlılık katsayısı ise $\alpha=.74$ olarak bulunmuştur. Ölçekte değerlendirme ölçeği olarak 5’li Likert Ölçeği kullanılmıştır. Ölçekte her bir ifade için 1: Hiç Katılmıyorum, 2: Çok Az Katıllyorum, 3: Orta Düzeyde Katılıyorum, 4: Büyük Oranda Katılıyorum, 5: Tamamen Katılıyorum şeklinde bir tercih listesi düzenlenmiştir.

Araştırmada konaklama işletmelerinde çalışan yöneticilerinin işkolik davranışları ile yaşam doyumları arasındaki ilişkiyi belirlemeye yönelik olarak kurulan araştırma modeli Şekil 1'de gösterilmektedir. Model, demografik değişkenlere bağlı olarak işkoliklik ile yaşam doyumu arasındaki ilişkinin incelenmesi şeklinde planlanmıştır.

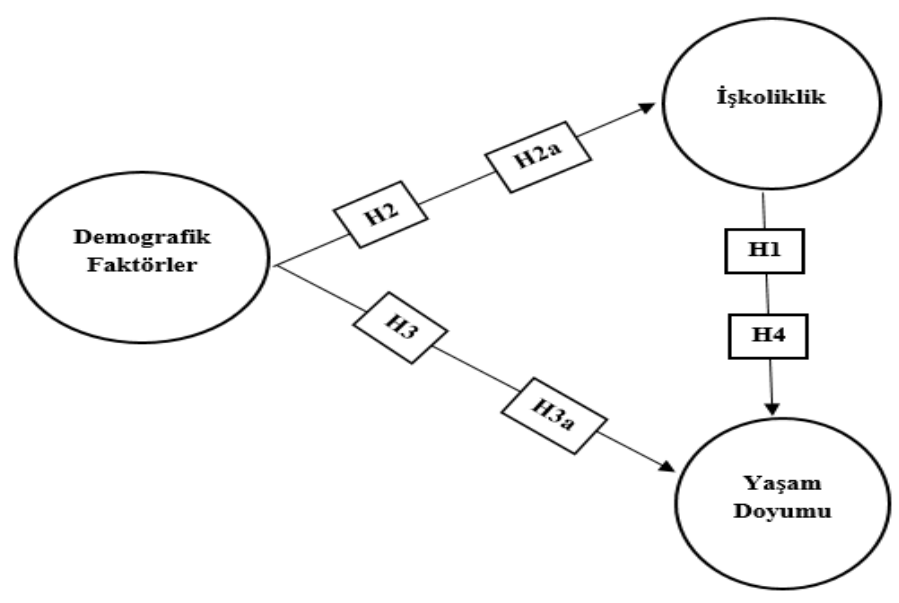

Şekil 1. Araştırma Modeli 
Araştırmada konaklama işletmeleri yöneticilerinin işkolik davranışları ile yaşam doyumu arasında anlamlı bir ilişki olduğu varsayılmaktadır. Ayrıca yöneticilerin işkolik davranışlarını ve yaşam doyumunu etkileyen bazı faktörlerin bulunduğu varsayılmaktadır. Bu çerçevede araştırma ile ilgili alan yazın taraması yapılmış ve araştırmanın hipotezleri oluşturulmuştur.

İşkoliklik ile alan yazın incelendiğinde, Burke ve diğerleri (2006) cinsiyet ile işkoliklik arasında, Serçeoğlu (2015) eğitim düzeyi ve işletmede çalışılan kademe arasında anlamlı bir ilişkinin olduğu tespit etmişlerdir. Yaşam doyumu ile ilgili alan yazın incelendiğinde, Dikmen (1995), cinsiyet ile yaşam doyumu arasında, Plagnol ve Easterline (2008), eğitim düzeyi ile yaşam doyumu arasında, Yetim (2001), eğitimin tek başına yaşam doyumunu etkilemediği kıdem, sosyal statü, gelir düzeyi ile birleşince yaşam doyumu arasında anlamlı farklılıkların belirlendiğini tespit etmişlerdir. Andreassen ve arkadaşları (2011) işkoliklik ile yaşam doyumu arasında negatif bir ilişki olduğu sonucuna ulaşmışlardır.

Alan yazından elde edilen verilerle ilişkili olarak aşağıda oluşturulan hipotezler test edilmiştir:

H1. İşkoliklik ile yaşam doyumu arasında anlamlı ve negatif yönlü bir ilişki vardır.

H2. İşkoliklik ile demografik özellikler (eğitim düzeyi, gelir düzeyi ve işletmede çalışılan kademe) arasında anlamlı bir ilişki vardır.

H2a. Araştırmaya katılanların işkolik davranışları cinsiyetlerine göre anlamlı bir farklılık göstermektedir.

H3. Yaşam doyumu ile demografik özellikler (eğitim düzeyi, gelir düzeyi ve işletmede çalışılan kademe) arasında anlamlı bir ilişki vardır.

H3a. Araştırmaya katılanların yaşam doyumları cinsiyetlerine göre anlamlı bir farklılık göstermektedir.

H4. İşkolikliğin yaşam doyumu üzerinde anlamlı bir etkisi vardır.

\section{BULGULAR}

Araştırmaya katılan yöneticilerin, sosyo-demografik özelliklerine göre dağılımları tanımlayıcı analizlerle (yüzde ve frekans) değerlendirilmiştir. Katılımcıların sosyo-demografik özellikleri Tablo 1'de verilmektedir.

Tablo 1. Katılımcıların Demografik Özellikleri

\begin{tabular}{|c|c|c|c|c|c|}
\hline Cinsiyet & $\mathrm{F}$ & $(\%)$ & Medeni Durum & $\mathrm{F}$ & $(\%)$ \\
\hline Erkek & 248 & 62.0 & Evli & 272 & 68.0 \\
\hline Kadın & 152 & 38.0 & Bekar & 128 & 32.0 \\
\hline Eğitim Düzeyi & $F$ & $(\%)$ & Günlük Çalışma Süresi & $\mathbf{F}$ & $(\%)$ \\
\hline Lise & 50 & 12.5 & 8 saat ve altı & 264 & 66.0 \\
\hline On Lisans & 173 & 43.2 & 9-11 saat arası & 127 & 31.8 \\
\hline Lisans & 177 & 44.3 & 12 saat ve üzeri & 9 & 2.2 \\
\hline $\begin{array}{l}\text { Yönetici Olduğunuz } \\
\text { Pozisyon }\end{array}$ & $\mathbf{F}$ & $(\%)$ & Aylık Gelir & $\mathbf{F}$ & $(\%)$ \\
\hline Şef & 99 & 24.7 & 1601-2400 TL arasi & 28 & 7.0 \\
\hline Müdür Yardımcısı & 67 & 16.8 & $2401-3200 \mathrm{TL}$ aras1 & 87 & 21.8 \\
\hline \multirow[t]{2}{*}{ Müdür } & 234 & 58.5 & $3201-4000 \mathrm{TL}$ aras1 & 171 & 42.7 \\
\hline & & & 4001 TL ve üzeri & 114 & 28.5 \\
\hline
\end{tabular}

Katılımcıların demografik özellikleri incelendiğinde, \%38,0'i kadın, \%62,0'si erkeklerden oluştuğu görülmektedir. Araştırmaya katılan konaklama işletmeleri yöneticilerinin \%68,0'inin 
evli olduğu, \% 44,3'ünün lisans mezunu olduğu, \% 42,7'sinin 3201-4000 TL arası gelire sahip olduğu, \% 66,0'sının günlük çalışma saatinin 8 saat ve altı olduğu, $\% 58,5^{\prime}$ inin müdür pozisyonunda çalışmaktadır.

Saha araştırması sonucunda işkoliklik ölçeğinin güvenirliğini belirlemek üzere iç tutarlılık katsayıları (Cronbach Alpha) hesaplanarak aşağıda Tablo 2' de verilmektedir.

Tablo 2. İşkoliklik Ölçeğine İlişkin Güvenirlilik Analizi, Standart Sapma ve Aritmetik Ortalama Sonuçları $(\mathrm{N}=400)$

\begin{tabular}{|c|c|c|c|c|c|}
\hline \multicolumn{4}{|c|}{ İfade } & $\bar{x}$ & S.S \\
\hline \multirow{8}{*}{ 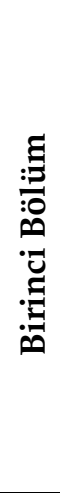 } & \multicolumn{3}{|c|}{ İşimi çoğu insanın sevdiğinden daha çok seviyorum. } & 4,13 & 0,91 \\
\hline & \multicolumn{3}{|c|}{ Çalışırken mola verince kendimi suçlu hissediyorum. } & 1,46 & 0,82 \\
\hline & \multicolumn{3}{|c|}{ Benim mesleğim işten daha çok eğlenceye benzer. } & 3,48 & 1,14 \\
\hline & \multicolumn{3}{|c|}{ İşim öyle ilginç ki çoğu zaman bana iş gibi görünmüyor. } & 3,40 & 1,17 \\
\hline & \multicolumn{3}{|c|}{$\begin{array}{l}\text { İşim gerçekten eğlenceli olduğu için benden beklenenden daha fazla } \\
\text { çalışırım. }\end{array}$} & 4,17 & 0,82 \\
\hline & \multicolumn{3}{|c|}{ İşte geçirdiğim zamanın çoğundan zevk alırım. } & 4,19 & 0,80 \\
\hline & \multicolumn{3}{|c|}{ İşimde hoşlanacak bir şey nadiren bulurum. } & 1,36 & 0,71 \\
\hline & \multicolumn{3}{|c|}{$\begin{array}{l}\text { Çalışırken olduğu kadar çalışmadığım zamanlarda bile vaktimi faydalı } \\
\text { bir şeylerle değerlendiririm. }\end{array}$} & 4,47 & 0,76 \\
\hline & \multicolumn{3}{|c|}{ Bazen sabahları kalktığımda, çalışmak için sabırsızlanırım. } & 2,45 & 1,23 \\
\hline & \multicolumn{3}{|c|}{$\begin{array}{l}\text { İlginç bir projeyle uğraştığımda kendimi ne denli keyifli hissettiğimi } \\
\text { anlatamam. }\end{array}$} & 4,10 & 0,73 \\
\hline : & \multicolumn{3}{|c|}{$\begin{array}{l}\text { İşten bir süreliğine uzak kaldığım zaman bile kendimi sürekli iş hakkında } \\
\text { düşünürken buluyorum. }\end{array}$} & 2,25 & 1,14 \\
\hline$\vdots 0$ & \multicolumn{3}{|c|}{ Uğraştı̆ıım iş ve diğer aktiviteler arasında çok fazla boş zamanım yok. } & 3,48 & 0,72 \\
\hline$\tilde{\mathscr{g}}$ & \multicolumn{3}{|c|}{$\begin{array}{l}\text { Çoğu zaman içimde beni çok çalışmaya güdüleyen bir şey var gibi } \\
\text { hissediyorum. }\end{array}$} & 3,62 & 0,89 \\
\hline & \multicolumn{3}{|c|}{ Bazen çalışmaktan o kadar çok hoşlanırım ki ara vermek bana zor gelir. } & 2,86 & 1,12 \\
\hline & \multicolumn{3}{|c|}{$\begin{array}{l}\text { Yapmak için verimli bir şey olmadığı zaman tatillerde sıkılırım ve } \\
\text { huzursuz olurum. }\end{array}$} & 2,27 & 1,08 \\
\hline & \multicolumn{3}{|c|}{ Diğer kişiler beni, aşırı çalışmaya meyilli biri gibi görür. } & 3,41 & 1,02 \\
\hline & Birinci Bölüm & İkinci Bölüm & \multicolumn{3}{|c|}{ Ölçek Geneli } \\
\hline & $\begin{array}{c}\text { Toplam Ortalama 26,66 } \\
\text { Toplam Varyans 18,12 } \\
\text { Standart Sapma 4,25 } \\
\text { Cronbach's Alpha ,72 }\end{array}$ & $\begin{array}{c}\text { Toplam Ortalama } 24,44 \\
\text { Toplam Varyans } 26,50 \\
\text { Standart Sapma 5,14 } \\
\text { Cronbach's Alpha ,78 }\end{array}$ & \multicolumn{3}{|c|}{$\begin{array}{c}\text { Toplam Ortalama 51,10 } \\
\text { Toplam Varyans } 69,40 \\
\text { Standart Sapma 8,33 } \\
\text { Cronbach's Alpha ,83 }\end{array}$} \\
\hline
\end{tabular}

Tablo 2' de İşkoliklik Ölçeğine ilişkin güvenirlilik analizi yapılmıştır. Güvenirliğin testi için yarıya bölme yöntemi (split-half method) kullanılmıştır. Bu test sonucunda; birinci bölüm (ilk 8 ifade) için 0,72 , ikinci bölüm (son 8 ifade) için 0,78 ve ölçeğin geneli için ise 0,83 Cronbach's Alpha değeri elde edilmiştir. Önermeler içerisinde en yüksek ortalama, "Çalışırken olduğu kadar çalışmadığım zamanlarda bile vaktimi faydalı bir şeylerle değerlendiririm." şeklindeki 8. ifadede $(x=4,47)$ gerçekleşirken, "İşimde hoşlanacak bir şey nadiren bulurum." şeklindeki 7. ifade $(x=1,36)$ ise en düşük katılım düzeyi olan ifade olarak belirlenmiştir.

Alan araştırması sonucunda yaşam doyumu ölçeğinin güvenirliğini belirlemek üzere iç tutarlılık katsayıları (Cronbach Alpha) hesaplanarak aşağıda Tablo 3'te verilmektedir. 
Tablo 3. Yaşam Doyumu Ölçeğine İlişkin Güvenirlilik Analizi, Standart Sapma ve Aritmetik Ortalama Sonuçları $(\mathrm{N}=400)$

\begin{tabular}{|c|c|c|c|c|c|}
\hline \multicolumn{4}{|c|}{ İfade } & $\bar{x}$ & S.S \\
\hline \multirow{3}{*}{ 苛 } & \multicolumn{3}{|c|}{ İdeallerime yakın bir yaşantım vardır. } & 3,81 & 0,82 \\
\hline & \multicolumn{3}{|c|}{ Yaşam koşullarım mükemmeldir. } & 3,11 & 0,90 \\
\hline & \multicolumn{3}{|l|}{ Yaşamımdan memnunum. } & 3,69 & 0,79 \\
\hline \multirow{2}{*}{ 可 } & \multicolumn{3}{|c|}{ Şimdiye kadar yaşamdan ist } & 3,70 & 0,80 \\
\hline & \multicolumn{3}{|c|}{$\begin{array}{l}\text { Tekrar dünyaya gelsem hayatımdaki hemen hemen hiçbir şeyi } \\
\text { değiştirmezdim. }\end{array}$} & 3,09 & 1,14 \\
\hline & Birinci Bölüm & İkinci Bölüm & \multicolumn{3}{|c|}{ Ölçeğin Geneli } \\
\hline & $\begin{array}{c}\text { Toplam Ortalama 10,61 } \\
\text { Toplam Varyans 4,98 } \\
\text { Standart Sapma 2,23 } \\
\text { Cronbach's Alpha ,86 }\end{array}$ & $\begin{array}{c}\text { Toplam Ortalama 6,79 } \\
\text { Toplam Varyans 3,16 } \\
\text { Standart Sapma 1,78 } \\
\text { Cronbach's Alpha ,75 }\end{array}$ & \multicolumn{3}{|c|}{$\begin{array}{c}\text { Toplam Ortalama } 17,40 \\
\text { Toplam Varyans } 14,71 \\
\text { Standart Sapma 3,83 } \\
\text { Cronbach's Alpha ,90 }\end{array}$} \\
\hline
\end{tabular}

Tablo 3'te Yaşam Doyumu Ölçeğine ilişkin güvenirlilik analizi yapılmıştır. Birinci bölüm (ilk 3 ifade) için 0,86 ikinci bölüm (son 2 ifade) için 0,75 ve ölçeğin geneli için ise 0,90 Cronbach's Alpha değeri elde edilmiştir. İfadelere bakıldığında, en yüksek ortalama $(x=3,81)$, “İdeallerime yakın bir yaşantım vardır." şeklindeki 1. ifadede gerçekleştirirken, "Tekrar dünyaya gelsem hayatımdaki hemen hemen hiçbir şeyi değiştirmezdim." şeklindeki 5. ifade $(x=3,09)$ ise en düşük katılım düzeyine sahip olan ifade olarak belirlenmiştir.

Konaklama işletmeleri yöneticilerinin cinsiyet değişkenine göre işkoliklik ve yaşam doyumuna ilişkin tek örnek t-testi sonuçları aşağıda Tablo 4'te yer almaktadır.

Tablo 4. Konaklama İşletmeleri Yöneticilerinin Cinsiyet Değişkenine Göre İşkoliklik ve Yaşam Doyumu Açısından Bağımsız Örneklem T-Testi Sonuçları

\begin{tabular}{|c|c|c|c|c|c|c|}
\hline & \multicolumn{2}{|c|}{ Levene Testi } & \multicolumn{3}{|c|}{ t-Testi } \\
\hline & & $\mathbf{F}$ & $\mathbf{P}$ & $\mathrm{T}$ & Sd & P (2-Uçlu) \\
\hline \multirow{5}{*}{ İşkoliklik } & Eşit Varyanslar & \multirow[t]{2}{*}{5,25} & \multirow[t]{2}{*}{,02 } & 3,95 & 398 & ,00 \\
\hline & Eşit Olmayan Varyanslar & & & 4,10 & 357,47 &, 00 \\
\hline & \multicolumn{3}{|l|}{ Cinsiyetiniz } & $\mathbf{N}$ & $x$ & S.S \\
\hline & \multicolumn{3}{|l|}{ Kadın } & 152 & 3,32 & ,46 \\
\hline & \multicolumn{3}{|l|}{ Erkek } & 248 & 3,11 &, 54 \\
\hline \multirow{5}{*}{$\begin{array}{c}\text { Yaşam } \\
\text { Doyumu }\end{array}$} & Eşit Varyanslar & \multirow[t]{2}{*}{1,34} & \multirow[t]{2}{*}{2,24} & 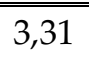 & 398 & ב,00 \\
\hline & Eşit Olmayan Varyanslar & & & 3,40 & 346,15 &, 00 \\
\hline & \multicolumn{3}{|l|}{ Cinsiyetiniz } & $\mathbf{N}$ & $X$ & S.S \\
\hline & \multicolumn{3}{|l|}{ Kadın } & 152 & 3,64 & ,70 \\
\hline & \multicolumn{3}{|l|}{ Erkek } & 248 & 3,38 & ,78 \\
\hline
\end{tabular}

Tablo 4'te cinsiyet değişkenine göre katılımcıların işkoliklik ve yaşam doyumuna ilişkin aritmetik ortalamaları verilmiştir. Analiz sonucunda, katılımcıların cinsiyetleri ile işkoliklik algılamaları arasında $(p=0,00)$ ve yaşam doyumu arasında $(p=0,00)$ anlamlı bir fark bulunmuştur. Elde edilen bu bulgulardan hareketle $\mathrm{H} 2 \mathrm{a}$ ve $\mathrm{H} 3 \mathrm{a}$ hipotezleri desteklenmiştir. Elde edilen bulgular sonucunda kadın yöneticilerin daha fazla işkolik eğilim gösterdiklerini ve yaşamdan daha fazla doyum sağladığı sonucuna ulaşılmıştır. 
Araştırmanın bu kısmında değişkenler arasındaki ilişki ve bu ilişkinin yönünü belirlemeye ilişkin korelasyon analizi sonuçları Tablo 5'te verilmektedir.

Tablo 5. Değişkenler Arasındaki Korelasyon Analizi Sonuçları

\begin{tabular}{|c|c|c|c|c|c|c|c|}
\hline & 1 & 2 & 3 & 4 & 5 & 6 & 7 \\
\hline Eğitim (1) & 1 & & & & & & \\
\hline Aylık Gelir(2) & $495^{* *}$ & 1 & & & & & \\
\hline Yönetici Olduğu Konum (3) & $295^{* *}$ & $605^{* *}$ & 1 & & & & \\
\hline Yaşam Doyumu (4) & $323^{* *}$ & $319^{* *}$ & $363^{* *}$ & 1 & & & \\
\hline İşkoliklik (5) & $207^{* *}$ & $231^{* *}$ & ,300** & ,638* & 1 & & \\
\hline
\end{tabular}

$\mathrm{Bu}$ analiz sonucunda, konaklama işletmeleri yöneticilerinin eğitim seviyesi ile yaşam doyumu arasında anlamlı ve pozitif yönlü $(\mathrm{r}=, 323, \mathrm{p}<0,01)$ bir ilişki olduğu görülmektedir. Konaklama işletmeleri yöneticilerinin eğitim seviyesi artıkça yaşamdan doyumları da artış göstermektedir. Konaklama işletmeleri yöneticilerinin geliri ile yaşam doyumu arasında anlamlı ve pozitif yönlü $(\mathrm{r}=, 319, \mathrm{p}<0,01)$ bir ilişki olduğu görülmektedir. Konaklama işletmeleri yöneticilerinin aylık gelirleri artıkça yaşamdan doyumları da artış göstermektedir. Konaklama işletmeleri yöneticilerinin konumu ile yaşam doyumu arasında anlamlı ve pozitif yönlü $(r=363, p<0,01)$ bir ilişki olduğu görülmektedir. Yöneticilerin işletmedeki konumları artış gösterdikçe yaşam doyumlarında artış görülmektedir. Bu bulgulardan hareketle H3 hipotezi desteklenmiştir.

Konaklama işletmeleri yöneticilerinin eğitim seviyesi ile işkoliklik arasında anlamlı ve pozitif yönlü $(r=207, p<0,01)$ bir ilişki olduğu görülmektedir. Konaklama işletmeleri yöneticilerinin eğitim seviyesi artıkça işkoliklik eğilimleri de artış göstermektedir. Konaklama işletmeleri yöneticilerinin geliri ile işkoliklik arasında anlamlı ve pozitif yönlü $(r=, 231, p<0,01)$ bir ilişki olduğu görülmektedir. Konaklama işletmeleri yöneticilerinin gelir seviyesi artıkça işkoliklik eğilimleri de artış göstermektedir. Konaklama işletmeleri yöneticilerinin konumu ile işkoliklik arasında anlamlı ve pozitif yönlü $(\mathrm{r}=, 300, \mathrm{p}<0,01)$ bir ilişki olduğu görülmektedir. Yöneticilerin işletmedeki konumları artış gösterdikçe işkoliklik eğilimleri de artış görülmektedir. Bu bulgulardan hareketle $\mathrm{H} 2$ hipotezi desteklenmiştir. Konaklama işletmeleri yöneticilerinin işkoliklik ile yaşam doyumu arasında anlamlı ve pozitif yönlü $(r=6638, p<0,01)$ bir ilişki olduğu görülmektedir. Bu bulgulardan hareketle, H1 hipotezi desteklenmemiştir. Araştırmadan elde edilen bulgular sonucunda işkolik yöneticilerin yaşamlarından doyum aldıkları söylenebilir. Yani işini çok seven, çalışmaya bağlı olan, hiç durmadan işini düşünen biri yaptığı işi severek yapacak ve bunun sonucunda yaşamından doyum alacaktır. Ayrıca elde ettiği gelir ve konum yükseldikçe birey daha fazla işkolik eğilim gösterdiğini ve bunun sonucunda yaşamından daha fazla doyum sağladığı sonucuna ulaşılmıştır.

İşkolikliğin yaşam doyumu üzerindeki etkisini ölçmek amacıyla regresyon analizi yapılmıştır. Analiz sonuçları aşağıdaki Tablo 6' da verilmektedir.

Tablo 6. Regresyon Analizi Sonuçları

\begin{tabular}{|l|l|l|l|l|l|l|}
\hline Değişkenler & B & Std. Hata & Beta & T & P \\
\hline \multirow{4}{*}{$\begin{array}{l}\text { Yaşam } \\
\text { Doyumu }\end{array}$} & Sabit & 1,691 & 0,093 & & 18,106 &, 000 \\
\cline { 2 - 7 } & İşkoliklik &, 433 & 0,026 &, 638 & 16,520 &, 000 \\
\cline { 2 - 7 } & $\mathbf{R}^{2}=\mathbf{0 , 4 0 7} ; \mathbf{F}=\mathbf{2 7 2 , 9 1 6 ;} \mathbf{P}=\mathbf{0 , 0 0 0}$ & & \\
\hline
\end{tabular}


Tablo 6'da konaklama işletmeleri yöneticilerinin işkoliklik davranışlarına ilişkin algılarının yaşam doyumu düzeylerine etkisini belirlemek amaciyla basit doğrusal regresyon analizi yapılmıştır. Yaşam doyumu bağımlı, işkoliklik unsurunun bağımsız değişken olarak belirlendiği regresyon modeli anlamlı bulunmuştur $(\mathrm{F}=272,916 ; \mathrm{p}=0,000<0,05)$. Bağımsız değişken olan işkoliklik, bağımlı değişken olan yaşam doyumunu açıklama oranı \% 40,7 (R2=0,407)'dir. Bu doğrultuda H4 hipotezi desteklenmiştir.

Araştırma kapsamında işkoliklik ile yaşam doyumu arasında anlamlı bir ilişki olduğu belirlenmiştir. Bu durumda işkolik yöneticilerin yaşamlarından doyum aldıkları söylenebilir. İşkoliklik ile demografik özellikler arasında anlamlı bir ilişki vardır. Araştırmada konaklama işletmelerinde çalışan kadın yöneticiler, erkeklere göre daha fazla işkolik eğilimlidir. Kadın işgörenlerin işkoliklik düzeyi gerek erkek işgörenler ile rekabet edebilmek adına, gerekse erkek işgörenlere göre daha fazla kariyer problemleri yaşamaları, işlerini kaybetme korkuları ve kendilerini çalışmaya zorunlu hissetmeleri gibi sebeplerden dolayı daha yüksektir. Araştırmada kadın yöneticilerin, erkek yöneticilere kıyasla yaşam doyumları daha yüksektir.

\section{SONUÇ ve ÖNERILER}

Araştırmaya ilişkin analiz sonuçları incelendiğinde işkolik davranışın çok çalışmak ile karıştırıldığını buna bağlı olarak işkolikliğin olumlu bir davranış olarak algılanmasına neden olduğu anlaşılmıştır. Araştırmaya katılan konaklama işletmeleri yöneticilerinin işkolikliği olumlu olarak değerlendirmeleri yaşam doyumlarının da yüksek çıkmasına neden olmuştur. Araştırmanın başında işkolik eğilim gösteren bireylerin yaşamlarından aldıkları doyumun düşük olacağı varsayılmıştır. Ancak işkolik davranışın gerek toplum içinde gerekse örgütlerde olumlu bir davranış olarak düşünülmesi araştırmada beklenilen sonuçların tam tersi sonuçlar çıkmasına neden olmuştur.

Alan yazın incelendiğinde cinsiyetin işkoliklikle ilişkili olduğuna dair bulgulara rastlanmıştır. Araştırmaya ilişkin bulgular çoğunluklu olarak erkeklerin kadınlara oranla daha fazla işkoliklik eğiliminde oldukları tespit edilmiştir (Burke vd., 2006; Yılmaz vd., 2014). Bunun sebebinin ise kadınların yoğun iş temposunun yanı sıra ev işleriyle de ilgilenmesi ve bu yüzden de işten zevk alma oranlarının düşük olmasıyla ilişkilendirilmiştir. Ancak araştırmada kadın yöneticilerin erkek yöneticilerden daha fazla işkolik davranış göstermektedir. Bunun sebebinin de turizm sektöründe erkek egemenliğinin de yönetimin ağırlıklı olması kadın çalışanların bulundukları pozisyonu kaybetme korkusuyla daha fazla çalışmalarına ve işkolik davranış göstermelerine sebep olduğu düşünülmektedir.

Araştırmada elde edilen sonuçlara göre gelir düzeyi yüksek olan yöneticilerin işkolik eğilimlerinin de yüksek olduğu gözlenmiştir. Bireylerin çalışmadaki öncelikli nedeni ekonomik kazanç sağlamaktır. Bireylerin elde ettikleri kazanç arttıkça işlerine olan bağlılığı da artmaktadır. $\mathrm{Bu}$ durum bireylerin işkolik olmalarında önemli bir etmendir. Alan yazındaki çalışmalar araştırmamızın sonuçlarını destekler niteliktedir. İlgili yazın incelendiğinde işkolikliğin çalışılan kademeyle de ilişkilendirildiği görülmüştür. Araştırma sonuçlarına göre, çalışılan kademenin işkolikliği pozitif etkileyebileceği ve kıdem olarak ilerlemenin işkolikliği tetikleyebileceği tespit edilmiştir. Bu doğrultuda işletmede çalışılan kademe yükseldikçe işkoliklik düzeyinin artacağını söylemek mümkündür. Araştırmada gelir düzeyi yüksek olan yöneticilerin yaşam doyumlarının yüksek olduğu sonucuna ulaşılmıştır. İlgili yazında yaşam doyumu ile en çok ilişkilendirilen faktör gelir düzeyidir ve aralarında genellikle olumlu bir ilişki olduğu ifade edilmektedir (Keser, 2003; Doğan ve Şahin, 2015). Bireylerin gelir seviyesi yüksek ise yaşam doyumların da yüksek olacağına ilişkin bir kabul edilmişlik söz konusudur. Bireyin gelir seviyesinin yüksek olması alım gücünü artıracak ve arzu edilen ihtiyaçları kolaylıkla temin edebileceğinden dolayı yaşam 
doyumu da yüksek olacaktır, gelir seviyesinin düşük olması bireyin arzu ettiği ihtiyaçları karşılanmasında zorluk yaşamasına dolayısıyla yaşam doyumunun düşük olmasına sebep olacaktır.

- Toplumda işkolikliği olumlu olarak nitelendiren ve işkoliklik davranışının kişiye ve işletmeye oldukça fayda sağlayacağına ilişkin genel kanaat söz konusudur. Ancak işkoliklik düşünülenin aksine bireyde ve örgütte birçok olumsuz etkilere neden olmaktadır. İşkolikliğin olumlu olduğuna ilişkin bu genel kanaatle mücadele etmek için İKY departmanına önemli görevler düşmektedir. İKY departmanı işkolikliğin olumsuz etkilerine ilişkin işgörenleri bilinçlendirmek ve bilgilendirmek amacıyla seminerler düzenleyerek işgörenlerin işkolik olmalarının önüne geçebilir.

- İşgörenlerin işkolik olmalarında en önemli etkenlerden biri de örgütlerin işgörenlerin daha çok çalışmaları için başvurmuş oldukları ödüllendirme sistemidir. İşgörenler yöneticilerin dikkatini çekmek, ödülleri alabilmek ve kariyerlerinde gelişme imkânı sağlayabilmek için işkolik davranışlar sergilemeye başlamaktadırlar. İşkolik çalışanlar, örgüte kısa vadede katkı sağlıyor olsalar da uzun vadede olumsuz sonuçlara neden olabilmektedir. Örgütlerin bu sorunlar ile karş1 karşıya kalmamaları için işkolikliği teşvik edici bu uygulamalar yerine, verimli çalışanların ödüllendirildiği bir sistem geliştirmeleri gerekmektedir.

- Araştırmanın sonucunda kadın yöneticilerin erkek yöneticilere oranla daha fazla işkolik eğilim gösterdiği görülmektedir. Bunun nedeni de kadınların erkeklere göre daha fazla kariyer sorunları yaşaması, işlerini kaybetme korkuları ve kendilerini daha fazla çalışmaya zorunlu hissetmeleri sayılabilir. Bu durumun yaşanmaması için örgüt içinde kadın ve erkeklerin eşit şartlarda gerekli çalışma ortam koşullarını sağlanmalı ve özellikle terfi konularında adil bir düzen oluşturulması gerekmektedir.

- İşkolik bireylerin çalışma arkadaşlarıyla iletişimlerinin zayıf olduğu ve bunun sonucunda asosyal bireylere dönüştüğü görülmüştür. Bu doğrultuda örgüt içi iletişimin kuvvetlendirilmeli, çalışanların birbirlerini daha iyi tanıyabilecekleri ve paylaşımlarda bulunabilecekleri iş dışı aktiviteler yapılması örgüt içindeki işkoliklik düzeyinin azalmasını sağlayacaktır.

\section{KAYNAKÇA}

Akın, U. ve Oğuz, E. (2010). Öğretmenlerin İşkoliklik ve Tükenmişlik Düzeylerinin İlişkisi ve Çeşitli Değişkenler Açısından İncelenmesi. Kuram ve Uygulamada Eğitim Yönetimi Dergisi, 16 (3): 309-327.

Altınkurt, Y. ve Yılmaz, K. (2015). Farklı Çalışan Tipindeki Okul Yöneticilerinin İşkoliklik Eğilimleri ve İş Doyumları. Uluslararası Eğitim Bilimleri Dergisi, 2 (5): 225-236.

Andreassen, C. S., Hetland, J., Molde, H. and Pallesen, S. (2011). Workaholism and Potential Outcomes in Well-Being and Health in A Cross-Occupational Sample. Stress \& Health, 27 (3): 209214.

Bakker, A. B., Demerouti, E. and Burke, R. (2009). Workaholism and Relationship Quality: A Spillover-Crossover Perspective. Journal of Occupational Health Psychology, 14, $23-33$.

Balducci, C., Cecchin, M., Fraccaroli, F. and Schaufeli, W. B. (2012). Exploring the Relationship Between Workaholism and Workplace Aggressive Behaviour: The Role of Job-Related Emotion. Personality and Individual Differences, 53, 629-634.

Bonebright, C. A., Clay, D. L. and Ankenmann, R. D. (2000). The Relationship of Workaholism with Work-Life Conflict, Life Satisfaction and Purpose in Life. Journal of Counseling Psychology, $47,469-477$. 
Brady, B. R., Vodanovich S. J. and Rotunda R. (2008). The Impact of Workaholism on WorkFamily Conflict, Job Satisfaction, and Perception of Leisure Activities. The Psychologist-Manager Journal, 11 (2): 241-263.

Broeck, A.V.D., Schreurs, B., Witte, H.D., Vansteenkiste, M., Germeys, F. and Schaufeli, W. (2011). Understanding Workaholics Motivations: A Self Determination Perspective, Applied Psychology: An International Review, 60 (4): 600-621.

Buelens, M. and Poelmans, S. (2004). Enriching the Spence and Robbins Typology of Workaholism Demographic, Motivational and Organizational Correlates. Journal of Organizational Change Management, 17 (5): 440-458.

Burke, R. J. (2000). Workaholism in Organizations: Concepts, Results and Future Research Directions. International Journal of Management Reviews, 2 (1): 1-16.

Burke, R. J. (2001). Workaholism Components, Job Satisfaction and Career Progress. Journal of Applied Social Psychology, 31 (11): 2339-2356.

Burke, R. J., Matthiesen, B. S. and Pallesen, S. (2006). Workaholism, Organizational Life and WellBeing of Norwegian Nursing Staff. Career Development International, 11 (5): 463-477.

Burke, R. J., Richardsen, A. M. and Mortinussen, M. (2004). Workaholism Among Norwegian Managers Work and well-being Outcomes. Journal of Organizational Change Management, 17 (5): $459-470$.

Büber, M. (2017). Çalışanların Tükenmişlik Düzeylerinin İş Doyumu ve Yaşam Doyumu Üzerine Etkisi: Balıkçı Sınıfı Gemi Adamları Üzerine Bir Araştırma. Yayımlanmamış Yüksek Lisans Tezi, Dokuz Eylül Üniversitesi Sosyal Bilimler Enstitüsü, İzmir.

Christopher, J. C. (1999). Situating Psychological Well-being: Exploring the Cultural Roots of Its Theory and Research. Journal of Counseling \& Development, 77, (2): 141-153.

Diener, E. (1994). Assesing Subjective Well-Being: Progress and Opportunities. Social Indicators Research, 31, 103-157.

Diener, E. F., Horwitz, J. and Emmons, R. A. (1985). Happiness of the Very Wealthy. Social Indicators Research, 16, 263-274.

Diener, E., Emmons, R. A., Larsen, R. J. and Griffin, S. (1985a). The Satisfaction with Life Scale. Journal of Personality Assessment, 49 (1): 71-75.

Dikmen, A. A. (1995). İş Doyumu ve Yaşam Doyumu İlişkisi. Ankara Üniversitesi Siyasal Bilgiler Fakültesi Dergisi, 3 (4): 115-140.

Doğan, S. ve Şahin, F. (2015). Kendi Kendine Liderlik Stratejilerinin Yaşam Doyumu Üzerine Etkileri. S. Doğan (Editör). Yaşam Doyumu (1. Baskı) 131-145. Ankara: Nobel Akademik Yayıncılık.

Dosaliyeva, D. (2009). İşkolikliğin Örgütsel Bağlllık Üzerindeki Etkisi. Yayımlanmamış Yüksek Lisans Tezi, Sakarya Üniversitesi Sosyal Bilimler Enstitüsü, Sakarya.

Dost Tuzgöl, M. (2007). Üniversite Öğrencilerinin Yaşam Doyumunun Bazı Değişkenlere Göre İncelenmesi. Pamukkale Üniversitesi Eğitim Fakültesi Dergisi, 2 (22): 132-143.

Dündar, S. (1993). Teorik Çerçeve İçinde Yaşamdan Duyulan Tatmin Kavramı. Yönetim İstanbul Üniversitesi İşletme Fakültesi İşletme İktisadı Enstitüsü Dergisi, 15, 49-55.

Fujimoto, T. (2014). Workaholism and Mental and Physical Health. Japon Labor Review, 11 (1): 5067. 
Gürel Buldurcu, E. B. ve Altunoğlu, A. E. (2016). İşkoliklik, İş Stresi ve Yaşam Doyumu Arasındaki İlişkilerin İncelenmesi: Muğla İlinde Bir Araştırma. Uluslararası Sosyal Araştırmalar Dergisi, 9 (42): 1431-1438.

Harpaz, I. and Snir, R. (2003). Workaholism: Its Definition and Nature. Human Relations, 56 (3): 291-319.

Hill, E. J., Hawkins, J.A., Ferris, M. and Weitzman, M. (2001). Finding an Extra Day a Week: The Positive Influence of Perceived Job Flexibility on Work and Family Life Balance. Family Relations, 50 (1): 49-58.

Jonstone, A. and Jonston, L. (2005). The Relationship Between Organizational Climate, Occupational Type and Workaholism. New Zealand Journal of Psychology, 34 (3): 181-188.

Kanai, A. and Wakabayashi M. (2001). Workaholism Among Japanese Blue-Collar Employees. International Journal of Stress Management, 8 (2): 129-145.

Karabacak, G. (2013). İş- Aile Çatışmasının İş ve Yaşam Doyumuna Etkilerin İş Stresi ve Algglanan Sosyal Destek Açısından Otel Personeli Üzerinde İncelenmesi. Yayınlanmamış Doktora Tezi, Adnan Menderes Üniversitesi Sosyal Bilimler Enstitüsü, Aydın.

Kart, M. E. (2005). Reability and Validity of the Workaholism Battery (Work-Bat): Turkish Form. Social Behavior and Personality, 33 (6): 609-618.

Keser, A. (2003). Çalışmanın Anlamı, İnsan Yaşamındaki Yeri ve Yaşam Doyumu Üzerinde Bir Uygulama. Yayımlanmamış Doktora Tezi, Uludağ Üniversitesi Sosyal Bilimler Enstitüsü, Bursa.

Larsen, R. J., Diener, E. and Emmons, R. A. (1985). An Evolution of Subjective Well-Being Measures. Social Indicators Research, 17, 1-17.

Libano, M. D., Llorens, S., Salanova, M. and Schaufeli, W. (2010). Validity of a Brief Workaholism Scale. Psicothema, 22 (1): 143-150.

Lindfors, P.M., Meretoja, O.A., Töyry, S.M., Luukkonen, R.A., Elovainio, M.J. and Leino, T.J. (2007). Job Satisfaction, Work Ability and Life Satisfaction among Finnish Anaesthesiologists. Acta Anaesthesiologica Scandivia, 51 (7): 815-822.

Machlowitz, M. (1979). Determining the Effects of Workaholism. Dissertation Abstracts International, 40, 480-481.

McMillan, L.H.W., O'Driscoll, P. M. and E.C. Brady. (2004). The Impact of Workaholism on Personal Relationships. British Journal of Guidance and Counselling, 32 (2): 171-186.

Mudrack, P. E. and Naughton, T. J. (2001). The Assessment of Workaholism as Behavioral Tendencies: Scale Development and Preliminary Empirical Testing. International Journal of Stress Management, 8, 93-111.

Müller, W. and Schotter, A. (2010). Workaholics and Dropouts in Organizations. Journal of the European Economic Association, 8 (4): 717-743.

Myers, D. G. and Diener, E. (1995). Who is happy?. Psychological Science, 6, 10-19.

Neugarten, B. L., Havighurst, R. J. and Tobin, S. S. (1961). The Measurement of Life Satisfaction. Journal of Gerontology, 16, 134-143.

Özdemir, H. (2013). Sınıf Öğretmenlerinin İşkoliklik Eğilimlerinin İncelenmesi, Yayımlanmamış Yüksek Lisans Tezi, Marmara Üniversitesi Eğitim Bilimleri Enstitüsü, İstanbul. 
Özsoy, E., Filiz, B. ve Semiz, T. (2015). İşkoliklik ve Çalışmaya Tutkunluk Arasındaki İlişkiyi Belirlemeye Yönelik Sağlık Sektöründe Bir Araştırma. Sosyal ve Beşeri Bilimler Dergisi, 5 (2): 59-68.

Peiperl, M. and Jones, B. (2001). Workaholics and Overworkers: Productivity or Pathology?. Group \& Organization Management, 26, 369-393.

Plagnol, A. C. and Easterline, R. A. (2008). Aspirations, Attainments, and Satisfaction: Life Cycle Differences Between American Women and Men. Journal of Happiness Studies, 9, 601-619.

Porter, G. (2001). Workaholic Tendencies and the High Potential for Stress Among Co-Workers. International Journal of Stress Management, 8 (2): 147-164.

Proctor, C.L., Linley, P.A. and Maltby, J. (2009). Youth Life Satisfaction: A Review of the Literature. Journal of Happiness Studies, 10, 583-630.

Robinson, B. E. (1996). Concurrent Validity of the Work Addiction Risk Test A Measure of Workaholism. Psychological Reports, 79 (3): 1313-1314.

Robinson, B. E. (1996a). The Psychosocial and Familial Dimensions of Work Addiction: Preliminary Perspectives and Hypotheses. Journal of Counseling and Development, 74, 447-452.

Robinson, B. E. and Post, P. (1997). Risk of Addiction to Work and Family Functioning. Psychological Reports, 81, 91-95.

Russo, A. J. and Waters, E. L. (2006). Workaholic Worker Type Differences in Work-Family Conflict, the Moderating Role of Supervisor Support and Flexible Work Scheduling. Career Development International, 11 (5): 418-439.

Sahranç, Ü. (2007). Stres Kontrolü, Genel Öz-Yeterlik, Durumluk Kayg̨ ve Yaşam Doyumuyla İlişkili Bir Akış Modeli. Yayımlanmamış Doktora Tezi, Gazi Üniversitesi Eğitim Bilimleri Enstitüsü, Ankara.

Salihoğlu, G. H. (2014). Çalı̧anların Kariyer Yolculuğunda İşkolikliğin Rolü Üzerine Bankacılık Sektöründe Bir Araştırma. Yayımlanmamış Yüksek Lisans Tezi, Hitit Üniversitesi Sosyal Bilimler Enstitüsü, Çorum.

Salmela-Aro, K. and Nurmi, J. (2004). Employees' Motivational Orientation and Well-being at Work: A Person-oriented Approach. Journal of Organizational Change Management, 17 (5): 471-489.

Schaufeli, W. B., Bakker, A. B., Heijden, F. M. and Prins, J. T. (2009). Workaholism Among Medical Residents: It is the Combination of Working Excessively and Compulsively That Counts. International Journal of Stress Management, 16, 249-272.

Schaufeli, W., B., Taris, T., W. and Van Rhenen, W. (2008). Workaholism, Burnout and Work Engagement: Three of a Kind or Three Different Kinds of Employee Well-Being?. Applied Psychology: An International Review, 57, 173-203.

Schimmack, U., Diener, E. and Oishi, S. (2002). Life-satisfaction is a Momentary Judgment and a Stable Personality Characteristic: The Use of Chronically Accessible and Stable Sources. Journal of Personality, 70 (3): 345-384.

Serçeoğlu, N. (2015). Konaklama İşletmelerinde Çalışan Personelin İşkoliklik Eğilimleri ile Hizmet Odaklılık İlişkisi: Tra1 Bölgesinde Bir Araştırma, Yayımlanmamış Doktora Tezi, Atatürk Üniversitesi Sosyal Bilimler Enstitüsü, Erzurum.

Seybold, C. K. and Salomone, P. R. (1994). Understanding Workaholism: A Review of Causes and Counseling Approaches. Journal of Counseling \& Development, 73, 4-9. 
Shimazu, A. and Schaufeli, W.B. (2009). Is Workaholism Good or Bad for Employee Well-being? the Distinctiveness of Workaholism and Work Engagement among Japanese Employees. Industrial Health, 47, 495-502.

Shimazu, A., Demerouti, E., Bakker, A.B., Shimada, K. and Kawakami, N. (2011). Workaholism and Well-being Among Japanese Dualearner Couples: A Spillover-crossover Perspective. Social Science \& Medicine, 73 (3): 399-409.

Snir, R. and Harpaz I. (2004). Attitudinal and Demographic Antecedents of Workaholism. Journal of Organizational Change Management, 17 (5): 520-536.

Snir, R. and Zohar, D. (2008). Workaholism as Discretionary Time Investment at Work: An Experience-sampling Study. Applied Psychology: An International Review, 57, 109-127.

Snir, R., Harpaz, I. and Burke, R. (2006). Workaholism in Organizations: New Research Directions. Career Development International, 11 (5): 369-373.

Spence, J., T. and Robbins, A., S. (1992). Workaholism: Definition, Measurement and Preliminary Results. Journal of Personality Assessment, 58 (1): 160-178.

Taris, T. W., Schaufeli, W. B. and Verhoeven, L. C. (2005). Workaholism in the Netherlands: Measurement and Implications for Job Strain and Work-Nonwork Conflict. Applied Psychology: An International Review, 54 (1): 37-60.

Temel, A. (2006). Organizasyonlarda İşkolizm ve İşkolik Çalışanlar. "İş, Güç" Endüstri İlişkileri ve Insan Kaynakları Dergisi, 8 (2): 104-127

Tiftik, H. and Zincirkıran, M. (2014). A Study on Employees in Context of Organizational Commitment, Job Performance, Burnout and Workaholism: A Research on Cashiers. International Journal of Sciences: Basic and Applied Research, 15 (1): 171-184.

Veenhoven. R. (2000). The Four Qualities of Life, Ordering Concepts and Measures of the Good Life. Journal of Happiness Studies, 1, 1-39.

Vodanovich, S. J., Piotrowski, C. and Wallace J. C. (2007). The Relationship Between Workaholism and Health: A Report of Negative Findings. Organization Development Journal, 25 (1): 70-75.

West, R. (2001). Theories of Addiction. Addiction, 96 (1): 3-13.

Yaniv, G. (2011). Workaholism and Marital Estrangement: A Rational Choice Perspective. Mathematical Social Sciences, 61, 104-108.

Yetim, Ü. (1991). Kişisel Projelerin Organizasyonu ve Örüntüsü Açısından Yaşam Doyumu. Yayımlanmamış Doktora Tezi, Ege Üniversitesi Sosyal Bilimler Enstitüsü, İzmir.

Yetim, Ü. (2001). Toplumdan Bireye Mutluluk Resimleri, İstanbul: Bağlam Yayıncılık.

Yilmaz, K., Altınkurt, Y. and Kesim, E. (2014). The Relationship Between School Climate and the Workaholism Tendencies of Teachers. Anthropologist, 18 (2): 277-288.

Zhao, R. X., Qu H. and Ghiselli, R. (2011). Examining the Relationship of Work-Family Conflict to Job and Life Satisfaction: A Case of Hotel Sales Managers. International Journal of Hospitality Management, 30, 46-54.

Zincirkıran, M. (2014). İşkoliklik İş-Aile Çatışması İlişkisinin Yapısal Eşitlik Modeli ile İncelenmesi: Sağlık İşletmelerinde Bir Uygulama. Finans Politik \& Ekonomik Yorumlar, 51 (590): 103-114. 